STUDIA EUROPAEA GNESNENSIA 18/2018

ISSN 2082-5951

DOI 10.14746/seg.2018.18.21

Krzysztof Moraczewski

https://orcid.org/0000-0002-8919-2568

(Poznań)

\title{
RACJONALNOŚĆ DZIAŁANIA \\ I JEJ OGRANICZENIA
}

\section{Abstract}

The article is discusses possible limitations of the rationalistic concept of human action within cultural theory. Here, rationality of human action is construed in terms of decision theory. Two kinds of limitations are considered: (1) resulting from non-rationalistic conceptions of human action; (2) implied by anti-individualistic approaches to socio-cultural phenomena, especially structuralist and functionalist ones. Proposed conclusions aim for a reconciliation of rationalistic theory of action and principal premises of cultural materialism.

\section{Key words}

Culture, rationality, functionalism, cultural materialism 


\section{WPROWADZENIE}

Teoretyczne sposoby wyjaśniania ludzkich działań można podzielić na dwie zasadniczo odmienne grupy, z których pierwsza cechuje się względną spójnością, tzn. obejmuje stanowiska, których rekonstrukcja logiczna pozwala spodziewać się możliwości ich uzgodnienia, a druga stanowi grupę stanowisk często zasadniczo nieuzgadnialnych.

Do pierwszej grupy włączyłbym te koncepcje, które zakładają, że ludzkie działanie określane jest przez pewne czynniki świadomościowe, przy czym dokładniejsza eksplikacja tych czynników może się różnic, obejmując sądy normatywne i dyrektywalne, wyobrażenia czy też jeszcze inaczej określone przekonania. Za każdym razem chodzi jednak o rozmaite uszczegółowienia wchodzących $\mathrm{w}$ rachubę treści świadomości, które tradycja antropologii kognitywnej każe najogólniej określać mianem „wiedzy kulturowej”. Miano to bywa kłopotliwe jedynie przez nieuchronną dwuznaczność, jaka wiąże się z używaniem terminu „wiedza” zarówno na określenie treści badanej świadomości, jak i efektu naukowego ich badania (wiedzy w znaczeniu episteme). Cechą wspólną tych koncepcji jest także konieczność przyjęcia, explicite lub implicite, pewnej niezbędnej reguły, pełniącej - bez względu na swój status logiczne funkcje prawa i wiążącej w sposób konsekwentny określone treści świadomości z samym działaniem. Tego rodzaju regułą jest na przykład zasada wprowadzana przez Jerzego Kmitę w jego koncepcji kultury i zwana

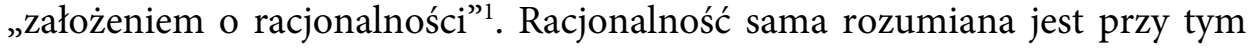
$\mathrm{w}$ sensie teoriodecyzyjnym, a więc bez powiązania $\mathrm{z}$ jakimikolwiek substancjalnym ujęciem racjonalności lub rozumu. Założenie o racjonalności pozwala Kmicie skonstruować typ zależności pomiędzy przekonaniami a działaniem, określany jako uwarunkowanie subiektywno-racjonalne. Podkreślmy, że jakiś typ tego założenia, bez względu na nazwę i choćby jedynie implicite, musi zostać przyjęty przez każdą koncepcję, która chce ująć zależności między przekonaniami a działaniem inaczej niż jako losowe. Zbiorcze określenie tej grupy koncepcji jako koncepcji działania racjonalnego nie powinno więc budzić sprzeciwów.

Grupę drugą koncepcji wyjaśniających ludzkie działania wiąże jedynie odrzucenie racjonalistycznej wykładni tego działania, a więc determinującego czy też określającego znaczenia treści ludzkiej świadomości. Na tym jednak zgoda się kończy, gdyż wchodzą tu w rachubę zarówno koncepcje indetermi-

${ }^{1}$ Kmita 1985. 
nistyczne, jak i skrajne czasami formy innego niż świadomościowy determinizmu. Koncepcji indeterministycznych nie trzeba tutaj dyskutować, i to nie dlatego, by należało je odrzucić bez dyskusji, ale dlatego, że w odniesieniu do teorii działania ich przyjęcie unieważnia sam projekt naukowego jej formułowania. Jeśli nie istnieje rozpoznawalny związek między ludzkim działaniem a jakimikolwiek jego otoczeniem, świadomościowym lub nie, to niemożliwe jest jego wyjaśnianie, a zatem jego teoria. Nie oznacza to jednak, że ludzka rzeczywistość nie posiada wymiarów innych niż działanie, które mogą ufundować możliwość innej wiedzy o tej rzeczywistości. Przełóżmy jednak dyskusję tego zagadnienia na inną okazję. Koncepcje deterministyczne z kolei różnią się między sobą zasadniczo.

\section{DZIAŁANIE INNE NIŻ RACJONALNE}

Nieracjonalistyczne koncepcje działania mogą zatem, po pierwsze, przyjmować zasadę zdeterminowania pojedynczego, podmiotowego działania przez czynniki inne niż świadomościowe: np. neurofizjologiczne lub nieświadomościowe w rozumieniu psychoanalitycznym.

Koncepcje neurofizjologiczne, podobnie jak indeterministyczne, także nie muszą być tutaj dyskutowane, chociaż z zasadniczo odmiennych powodów. Najpierw zatem, nikt nie przeczy istnieniu klasy ludzkich zachowań (nie nazywajmy ich, dla uniknięcia pomieszania, działaniami) o podłożu neurofizjologicznym. Należy tu na przykład cała sfera odruchowa. Teoria kultury nie podejmuje się wyjaśniania tej klasy zjawisk. Żadna jednak przekonująca koncepcja nie potrafiła dotąd zredukować ludzkich zachowań do odruchów. Możemy oczywiście zgodzić się, że indywidualne przekonania dadzą się zredukować do stanów centralnego układu nerwowego, ale ze zgody takiej niewiele nam przyjdzie. Neurofizjologowie nie potrafią jeszcze wskazać np. konkretnego stanu centralnego układu nerwowego odpowiadającego przekonaniu, że Jezus został poczęty bez grzechu pierworodnego, ani też serii stanów neurofizjologicznych, która odpowiadałaby przekształceniu tej teologicznej treści dogmatu o niepokalanym poczęciu w ludowy odpowiednik tego dogmatu, tzn. przekonanie o nienaruszonym przez narodziny Jezusa dziewictwie Maryi. Zaznaczmy przy tym bez fałszywej skromności, że humanistyczne metody historii kultury potrafią znakomicie wyjaśnić ten proces. Nawet jednak, gdyby jakaś przyszła neurofizjologia potrafiła wskazywać takie powiązania, nie zmieniłoby to faktu, że $\mathrm{z}$ logicznego punktu widzenia język humanistyki 
nie może zostać zredukowany do języka fizykalistycznego (nie ma tu potrzeby, by raz jeszcze omawiać przyczyny niemożliwości redukcji tego rodzaju, wskazywane m.in. przez Jerzego Kmitę i Donalda Davidsona²). Nawet jednak gdyby dalsze dociekania logiczne zniosły tę przeszkodę, to wciąż jeszcze nie byłoby jasne, czy tego rodzaju redukcja byłaby heurystycznie pożądana. Wyobraźmy sobie np. proces dystrybucji form sztuki barokowej z Rzymu poprzez Hiszpanię do Ameryki Łacińskiej wraz ze wszystkimi zmianami jej stylu i znaczeń albo wydarzenie takie, jak Rewolucja 1789 roku, opisane jako seria stanów indywidualnych centralnych układów nerwowych. Stopień komplikacji, a nawet sama obszerność tego opisu, czyniłyby go całkowicie nieoperatywnym. Możemy więc założyć, że dla zjawisk zbiorowych - którymi szczególnie interesuje się teoria kultury - a zwłaszcza dla diachronicznych zjawisk zbiorowych, redukcja neurofizjologiczna, choćby i możliwa, nigdy zapewne nie będzie opłacalna poznawczo.

Wyjaśnienia psychoanalityczne stwarzają innego rodzaju problem. Przyjmijmy za punkt wyjścia dla krótkiej dyskusji konsekwencje propozycji teoretycznych Zygmunta Freuda i Carla Gustava Junga, którym trudno byłoby odmówić atrakcyjności (w przeciwieństwie do popularnych interpretacji ich koncepcji). Pomijam koncepcje późniejsze, odwołujące się do Jacquesa Lacana $^{3}$ i Slavoja Žižka ${ }^{4}$, które narzucałyby jednoczesne rozpatrywanie zagadnień psychoanalizy, strukturalizmu i postrukturalizmu. Wymagałoby to osobnego obszernego opracowania.

Koncepcja Freudowska posiada dwie zasadnicze zalety. Po pierwsze, umożliwia odróżnienie klas ludzkich zachowań warunkowanych przez świadomie żywione przekonania (treści ego w rozumieniu Freudowskim) oraz zachowań stanowiących realizację treści popędowych $i d$, proponując zarazem przemyślaną koncepcję relacji między nimi. W szczególności koncepcja ta umożliwia rozpatrywanie zespołów czynności - praktyk społecznych - jako tworów hybrydycznych, w których zachowania należące do dwóch wymienionych klas wchodzą w szczególny układ. O ile dobrze rozumiem, taki właśnie charakter ma Freudowska interpretacja ekspresji artystycznej. Nie ma więc zasadniczej sprzeczności między freudyzmem a koncepcjami działania racjonalnego. Pozostaje natomiast interesujący problem pól ich prawomocności oraz wzajemnego usytuowania. Drugą zaletą koncepcji Freuda jest przekroczenie w jej ramach - co w psychologii wcale nie jest oczywiste - po-

\footnotetext{
${ }^{2}$ Kmita 1985, Davidson 1991.

${ }^{3}$ Lacan 1995.

${ }^{4}$ Žižek 2001.
} 
znawczego horyzontu metodologicznego indywidualizmu. Przekroczenie takie jest możliwe - co ma miejsce w późniejszej, drugiej wykładni topologii psychiki - dzięki pojęciu superego, jako miejsca usytuowania społecznych treści psychiki. Społeczny charakter superego wymusza poszerzenie koncepcji psychologicznej o teorię kultury. Kroku tego dokonał sam Freud w „Kulturze jako źródle cierpień" "S. Są to poważne zalety, które czyniłyby koncepcję Freuda kamieniem milowym w teorii ludzkiego działania, gdyby nie fundamentalna słabość freudyzmu: otóż nie istnieje żaden rozstrzygający argument na rzecz istnienia lub konieczności przyjęcia istnienia nieświadomości popędowej (id). Istnieją argumenty umożliwiające przyjęcie wcześniejszej Freudowskiej koncepcji przedświadomości jako siedliska treści wypartych, zapomnianych i nabytych w wyniku percepcji podprogowej, istnieją też poważne argumenty na rzecz Freudowskiej koncepcji mechanizmów obronnych ego, ale brak argumentów kluczowych na rzecz samej hipotezy id. W każdym razie, dopóki istotne argumenty na rzecz istnienia świadomości popędowej nie zostaną przedstawione, koncepcję Freuda należy traktować jako klasyczny przykład mnożenia bytów, tzn. przekroczenia rozsądnych granic ontologicznych akceptowalnej wiedzy. Argument, że koncepcji tej nigdy nie obalono, nie ma znaczenia, gdyż jak wiadomo ze względów logicznych obowiązek dowodu, w przypadku twierdzeń ontologicznych, spoczywa zawsze na głoszącym tezę pozytywną (dowód na nieistnienie nie jest możliwy). Argumenty takie, mimo wieku koncepcji Freuda, mogłyby się jeszcze - wbrew pozorom - pojawić, gdyż w wyniku lekceważenia przez wielu zwolenników tej koncepcji klasycznych wymogów wiedzy naukowej poszukiwania takiej argumentacji nigdy chyba konsekwentnie nie prowadzono. Być może szansa na jej przedstawienie tkwi w neurofizjologicznej interpretacji nieświadomości.

W zasadzie można by na tym - na nasze potrzeby - zakończyć kwestię koncepcji psychoanalitycznych. Warto jednak poświęcić kilka krótkich słów dociekaniom Junga, gdyż następuje w nich interesująca redukcja czynników społecznych do indywidualnych czynników psychicznych ${ }^{6}$. Jeśli Freud poprzez pojęcie superego wyposaża psychikę w treści o genezie społecznej i tym samym zrywa ze swoistym solipsyzmem swej pierwszej topologii psychiki, to Jung wyjaśnia z kolei podzielanie przez ludzi wyobrażeń, systemów symbolicznych itp. jako ekspresję nieświadomości zbiorowej, pojmowanej jako warstwa psychiki. Przyjmuje więc Jung - co u autora, który wprowadził do

\footnotetext{
${ }^{5}$ Freud 2013.

${ }^{6}$ Jung 1976.
} 
dyskusji zagadnienie nieświadomości zbiorowej, wydaje się na pierwszy rzut oka zaskakujące - perspektywę dość skrajnego psychologizmu. Nie trzeba zapewne dodawać, że Jungowska koncepcja nieświadomości zbiorowej znajduje się, niestety, w sytuacji metodologicznej nawet trudniejszej niż koncepcja nieświadomości popędowej.

Bez względu na konkluzje nawet tak pobieżna dyskusja sposobu, w jaki działanie ludzkie można wyjaśniać w kontekście klasycznego freudyzmu, unaocznia dwa możliwe ograniczenia tezy o racjonalnym - wciąż w sensie teoriodecyzyjnym - charakterze owego działania. Po pierwsze, ludzkie działania mogą należeć do różnych klas i być rozmaicie warunkowane, a więc nie ma powodu twierdzić, że teoria racjonalistyczna jest kompletną teorią ludzkich zachowań. Po drugie, poszczególne zachowania mogą mieć charakter pod względem swych uwarunkowań hybrydyczny, a więc ich wyjaśnienie musi angażować rozmaite - byle niesprzeczne - perspektywy teoretyczne. Oczywiście perspektywy te muszą być uprzednio logicznie zintegrowane - na drodze rekonstrukcji logicznej czy też parafrazy logicznej w rozumieniu Kazimierza Ajdukiewicza ${ }^{7}$ - pod rygorem osiągnięcia zwykłego eklektyzmu zamiast zintegrowanego wyjaśnienia.

\section{DZIAŁANIE W PERSPEKTYWIE METODOLOGICZNEGO ANTYINDYWIDUALIZMU}

Inne - i kluczowe - formy pozaświadomościowego wyjaśniania ludzkich działań przyjmują łączącą je perspektywę metodologicznego antyindywidualizmu, ale dzieli je przyjmowana, a przynajmniej dominująca, logiczna forma wyjaśnień. Jest nią albo wyjaśnianie funkcjonalne, albo też funkcyjne. Wyjaśnienia funkcjonalne dominują $\mathrm{np}$. $\mathrm{w}$ funkcjonalizmie antropologicznym i socjologicznym $\mathrm{z}$ tradycji Bolesława Malinowskiego ${ }^{8}$, w tym w neofunkcjonalnej propozycja Jeffreya C. Alexandra ${ }^{9}$, a także w rozmaitych formach najogólniej pojętego materializmu kulturowego, od materializmu historycznego poprzez ekologię kulturową Juliana $\mathrm{H}$. Stewarda ${ }^{10}$ aż po uproszczony - jeszcze będzie o tym uproszczeniu mowa - materializm kulturowy Marvina Harrisa ${ }^{11}$.

\footnotetext{
${ }^{7}$ Ajdukiewicz 1985

${ }^{8}$ Malinowski 2000.

${ }^{9}$ Alexander 1978.

${ }^{10}$ Steward 1972.

${ }^{11}$ Harris 2001.
} 
Po stronie koncepcji odwołujących się do wyjaśnień funkcyjnych należy umieścić przede wszystkim francuską antropologię strukturalną, i to począwszy od Marcela Maussa i jego „Szkicu o darze” ${ }^{12}$, pod warunkiem jednak zgody na taką interpretację tego tekstu, jaką proponował Claude Lévi-Strauss ${ }^{13}$ (Lévi-Strauss 2001). Odróżniając te dwie grupy koncepcji, przyjmuję oczywiście Kmitowe rozróżnienie wyjaśnień funkcyjnych i funkcjonalnych ${ }^{14}$. Ujmując sprawę najprościej, chodzi o rozróżnienie wyjaśnień opartych na potocznym rozumieniu funkcji jako roli elementu lub jego stanu - lub serii elementów i ich stanów - w pewnej większej całości i w utrzymywaniu stanów tej całości (wyjaśnianie funkcjonalne) od wyjaśnień opartych na matematycznym pojęciu funkcji jako przyporządkowania jednoznacznego (wyjaśnianie funkcyjne).

Przyjmując powyższe rozróżnienie i zakładając, że struktura - w rozumieniu Lévi-Straussa - stanowi całość, której elementy pozostają sobie wzajemnie przyporządkowane, tzn. że jedne elementy i ich stany są funkcjami w sensie matematycznym innych elementów i ich stanów, można powiedzieć, że chodzi w tym przypadku o strukturę funkcyjną. Należy ją zatem starannie odróżnić od struktur funkcjonalnych, w których elementy powiązane są przez rolę, jaką odgrywają w utrzymywaniu przez całość systemu jego własności. Struktury tego rodzaju, o jakich mówił strukturalizm i z którymi toczył grę poststrukturalizm, budzą jednak pewne zasadnicze wątpliwości. Otóż, jeżeli zależność funkcyjna łączy kwantyfikowalne stany rzeczy, to badając i mierząc zmienność argumentów, można stwierdzić, czy wartości im przyporządkowane zmieniają się w sposób rzeczywiście zależny od ruchu argumentów. $\mathrm{Z}$ taką sytuacją mamy do czynienia nie tylko w matematyce, ale też $\mathrm{w}$ zmatematyzowanym przyrodoznawstwie. Zmieniając siłę działającą na ciało i mierząc jej wartość, możemy następnie sprawdzić, czy przyspieszenie w ruchu tego ciała jest rzeczywiście funkcją działającej nań siły. Tymczasem analogicznego testu nie da się tak łatwo zbudować dla powiazań funkcyjnych między niekwantyfikowalnymi stanami rzeczy. Rozwiązaniem bywa więc kwantyfikacja arbitralna, stanowiąca zasadniczą słabość np. tak skądinąd wyrafinowanej metody badawczej jak kantometria Alana Lomaxa ${ }^{15} \mathrm{w}$ etnomuzykologii. Po drugie, wiążąc ze sobą elementy struktury jedynie formalnie (matematycznie), ryzykuje się niemożność odróżnienia powiązań zacho-

\footnotetext{
${ }^{12}$ Mauss 2001.

${ }^{13}$ Lévi-Strauss 2001.

${ }^{14}$ Kmita 1985.

${ }^{15}$ Lomax 1968.
} 
dzących między elementami powiązanymi przyczynowo lub funkcjonalnie a relacjami ustalonymi arbitralnie. Ostatecznie, w sensie teoriomnogościowym, między dowolnymi dwoma elementami pewnego zbioru zawsze dadzą się ustalić pewne czysto formalne relacje. Najczęściej zatem struktury, o jakich mówią strukturaliści, albo więc maskują zależności innego rodzaju niż funkcyjne (zwykle tak przez Lévi-Straussa pogardzane zależności funkcjonalne - przypomnijmy, że Malinowskiego interpretację funkcji jako roli uważał francuski badacz za przykre niezrozumienie myśli Maussa), albo też są systemami konstruowanymi arbitralnie. W każdym razie wobec niemożności innej niż arbitralna kwantyfikacji takich serii stanów rzeczy jak np. systemy mitologiczne - osobiście mam wątpliwości nawet w przypadku języka i pokrewieństwa (zwłaszcza pokrewieństwa) - nie ma możliwości skonstruowania jakiegokolwiek testu, który pozwoliłby na stwierdzenie istnienia bądź nieistnienia domniemanych stałych powiązań, a więc także rzekomej struktury funkcyjnej („struktury” po prostu w języku antropologii strukturalnej).

Zarzuty tego rodzaju nie stanowią zresztą krytyki strukturalizmu z zewnętrznego względem tej teorii punktu widzenia, bowiem sytuacja ta została rozpoznana i zdiagnozowana przez Lévi-Straussa w sławnym wstępie do „Myśli nieoswojonej”16. Rozumowanie to można najkrócej streścić następująco: każda struktura wymaga określenia punktu centralnego, który organizuje jej całość, nie istnieje jednak kryterium wyboru owego punktu; centrum struktury to jedynie puste locus, którego wypełnienie jest efektem pragmatycznej i arbitralnej decyzji etnologa, zachowującego się nie jak odkrywca reguł życia społecznego, lecz jak oportunistyczny majsterkowicz (bricoleur), troszczący się jedynie o to - jeśli wolno się tak wyrazić - żeby sklecona naprędce szopa jakoś przetrwała najbliższy deszcz. W tym pełnym rozczarowania rozpoznaniu francuskiego etnologa można widzieć punkt przełomowy, zaznaczający przejście od strukturalizmu do poststrukturalizmu. Punkt taki można też widzieć - $\mathrm{z}$ większą chyba słusznością - w interpretacji kłopotów Lévi-Straussa, jaką zaproponował Jacques Derrida w sławnym referacie „Struktura, znak i gra w dyskursie nauk humanistycznych"17. Zdaniem Derridy przełom polega nie na samym rozpoznaniu sytuacji bricoleura, ale na jej Nieztscheańskiej afirmacji, wbrew postawie nostalgii, próbującej ocalić sensowność struktury. Rozpoznając w myśli Lévi-Straussa tego rodzaju

${ }^{16}$ Lévi-Strauss 1969.

${ }^{17}$ Derrida 1986. 
nostalgię, Derrida miał niewątpliwie rację, o czym dogłębnie przekonuje lektura "Smutku tropików"18. Zaznaczmy jedynie, że afirmatywna zgoda Derridy też miała charakter eksperymentu, z którego można się wycofać, o czym wymownie zaświadcza zakończenie wspomnianego referatu. Tak rozumiany poststrukturalizm nie jest więc żadnego rodzaju kaprysem czy - jak chcieliby niektórzy - aberracją intelektualną, ponieważ artykułuje konkretne problemy teorii strukturalnej i mierzy się z nimi w sposób radykalny. Budzi jednak wątpliwość wyrażającą się w pytaniu o granice jego istotności. Jaką wagę ma poststrukturalizm dla tych sposobów teoretycznego ujmowania rzeczywistości społeczno-kulturowej, które jak np. ekologia kulturowa czy koncepcje długiego trwania, nigdy nie bazowały na strukturalistycznym pojęciu struktury (choć mogły posługiwać się słowem „struktura” w odmiennych znaczeniach)? Przyznajmy jednak, że wiele z kluczowych opcji dwudziestowiecznej humanistyki było tak czy inaczej zależnych od statusu „struktury strukturalistów”. Nic też więc dziwnego, że wyjście z poststrukturalistycznego „kryzysu” miało w dużym stopniu charakter rozwinięcia niestrukturalistycznych sposobów myślenia (np. Lakoff i Johnson w językoznawstwie ${ }^{19}$ ). Krytyka tego rodzaju może jednak prowadzić do zbyt łatwego przeoczenia lub odsunięcia zasadniczej, wciąż wymagającej przemyślenia (chociaż ostatnio, w dobie rozważań poświęconych różnym formom agency - niemodnej) lekcji strukturalizmu: że ludzkie działanie może być określone przez ponadindywidualne i niezależne od ludzkiej świadomości zestawy reguł („gramatyki”), niekoniecznie będące jednak „strukturami” w rozumieniu strukturalistów.

\section{MATERIALIZM KULTUROWY}

Najważniejsze z tych „ograniczników” mają zapewne charakter systemów funkcjonalnych $\mathrm{w}$ wyłożonym powyżej sensie. Zła sława funkcjonalizmu Malinowskiego ani też powszechnie znane zarzuty względem całej tradycji funkcjonalistycznej nie powinny przesłonić nam prostego faktu, że aby jakiekolwiek ludzkie społeczeństwo mogło istnieć, jego członkowie muszą: (1) jeść i pić; (2) zabezpieczyć się przed niekorzystnymi warunkami atmosferycznymi i konkurencją innych gatunków, a dzisiejsza ludzkość nie jest tu wyjątkiem rzadziej zjadają nas wilki i tygrysy, nad którymi człowiek odniósł zwycięstwo,

\footnotetext{
${ }^{18}$ Lévi-Strauss 1992.

${ }^{19}$ Lakoff i Johnson 1988.
} 
kto wie, czy nie samobójcze, ale wciąż konkurujemy z bakteriami, wirusami i pasożytami; (3) rozmnażać się, co obejmuje także wszystko, co niezbędne do doprowadzenia potomstwa do dalszej zdolności do rozmnażania się, a więc i opiekę nad tym potomstwem itd.; (4) w związku z tym, że zasadnicza część ewolucyjnych adaptacji Homo sapiens, takich jak techniki itp., nie jest przekazywana genetycznie, posiadać sposoby przekazywania dziedzictwa niegenetycznego, a więc w pierwszym rzędzie efektywne symboliczne systemy komunikacji, przede wszystkim język; (5) dysponować wystarczającą ilością energii dla realizacji (1)-(4). Bez względu na to, jak bardzo ktoś nie lubiłby funkcjonalizmu, a zwłaszcza słowa „potrzeba”, z wymogami tymi nie ma dyskusji. Argumenty na ich rzecz nie mają zresztą charakteru erudycyjnego, lecz przywołują podstawowe i nieusuwalne warunki ludzkiej egzystencji. Te konieczności i te warunki powodują, że funkcjonalizmu jako nastawienia nie zaś konkretnych jego artykulacji teoretycznych, które można odrzucać - nie da się z teorii kultury usunąć pod groźbą fantasmagoryczności tej teorii. Kształt współczesnego życia najbardziej uprzywilejowanych społeczeństw świata pozwala nie myśleć na co dzień o tym fundamentalnym zagadnieniu. Tygrysy zjadają ludzi w Bengalu, a nie w Holandii, żywność jest w sklepach (nieważne, skąd się tam bierze), ludność się reprodukuje, ponieważ zawsze pojawią się jacyś, zależnie od kraju, Polacy, Ukraińcy, Hindusi, Wietnamczycy, Turcy, Algierczycy lub Surinamczycy, których możemy przyjąć tylu, ilu nam potrzeba, i którzy wykonają prace, o których istnieniu nie chcemy pamiętać. To powoduje, że mamy pewien kłopot $z$ wymogiem (4), ale ostatecznie nie ma powodu, by czyszczący kanały Polak lub Tunezyjczyk brał udział w całości naszej reprodukcji symbolicznej. W sumie więc fundamentalne potrzeby są spełnione $\mathrm{i}$, taken for granted, niejako usunięte $\mathrm{z}$ pola refleksji. Teoretycy kultury, z reguły reprezentujący najbardziej uprzywilejowane klasy owych najbardziej uprzywilejowanych społeczeństw, aż nazbyt często podzielają owe iluzje wykorzenionej świadomości. Iluzja ta może sięgać aż do poziomu, który trudno nazwać inaczej niż utratą rozsądku, i widoczna jest choćby w głoszonych na serio przekonaniach, że rewolucja informatyczna może cokolwiek w tym zakresie zmienić. Przykro mi, ale nawet fanatyczny użytkownik mediów społecznościowych i gier wideo musi jeść (byli już Koreańczycy, którzy mimowolnie wykonali empiryczny test dla tego twierdzenia - wyniki są jednoznaczne). Nie bagatelizuję bynajmniej znaczenia tzw. rewolucji informatycznej, próbuję jedynie dobitnie i może złośliwie wskazać, że w podstawowym zakresie głównych ludzkich potrzeb nie zmieniła ona nic. Ewentualne zmiany w tym zakresie należą wciąż do sfer 
science-fiction bez specjalnego nacisku na science. Stwierdźmy zatem z całą mocą: bez względu na jakiekolwiek ludzkie intencje, przekonania, wartości itd. suma efektów ludzkich działań musi zawsze i w sposób bezwyjątkowy zapewnić realizację potrzeb (1)-(5). Nie podlega to dyskusji i nie dopuszcza wyjątków.

Dochodzimy więc do funkcjonalnej wykładni stanowiska tradycyjnie przeciwstawianego kognitywnym (świadomościowym) ujęciom rzeczywistości ludzkiej, dla którego Marvin Harris spopularyzował zbiorczą nazwę „materializm kulturowy" ${ }^{20}$. Nazwę tę, trafną, jak sądzę, chciałbym utrzymać, odrywając ją jednak w sposób zdecydowany od wersji materializmu kulturowego reprezentowanej przez samego Harrisa. Nazwałem wcześniej stanowisko amerykańskiego antropologa uproszczonym. Można je wyłożyć następująco: zawartość każdej określonej kultury, bez względu na jej interpretacje tubylcze, jest bezpośrednio zdeterminowana przez wymogi materialne. Same te wymogi można utożsamić z naszymi punktami (1)-(3) i (5), gdyż Harris wydaje się nie troszczyć o wymóg reprodukcji symbolicznej społeczeństw. W takiej wersji materializm kulturowy, stanowiący bez wątpienia najważniejsze ograniczenie racjonalistycznego ujęcia działań ludzkich - bowiem okazuje się, że istotną cechą ludzkiego działania jest funkcjonalność jego efektu, a nie struktura realizowanych przekonań (funkcja eliminuje sens) - jest niemożliwy do uzgodnienia $\mathrm{z}$ jakąkolwiek opcją racjonalistyczną. Jest to swoją drogą stanowisko co najmniej zaskakujące w przypadku autora, który jest nie tylko teoretykiem kultury, ale też wybitnym historykiem nauk o kulturze, świetnie zaznajomionym ze wszystkimi tego rodzaju problemami, o czym świadczy jego powszechnie używany podręcznik „The Rise of Anthropological Theory"21. Szczęśliwie, stanowisko Harrisa wydaje się z gruntu błędne $\mathrm{z}$ dwóch zasadniczych powodów.

Po pierwsze, Harris zdaje się zakładać, że między wymogami materialnymi życia społecznego a kształtem kultury zachodzi związek deterministyczny. Natura tego determinizmu nie zostaje bliżej określona, ale $\mathrm{z}$ wyjaśnień proponowanych przez amerykańskiego antropologa wynika, że jest to związek jakoś zbliżony do przyczynowo-skutkowego. Tymczasem, wbrew Harrisowi, autorzy tak do siebie niepodobni jak Arnold J. Toynbee, Fernand Braudel, Karol Marks, Lucien Febvre i Jerzy Kmita wydają się, bez względu na stosowaną terminologię, zgodni co do tego, że uwarunkowania materialne mają

\footnotetext{
${ }^{20}$ Harris 2001

${ }^{21}$ Harrids 2001a.
} 
charakter - wedle określenia Kmity - ramowy ${ }^{22}$. Zdaniem Kmity wszelkie uwarunkowania funkcjonalne cechują się ramowością, co oznacza, że potrzeba musi być zrealizowana, ale z punktu widzenia systemu „zgłaszającego potrzebę" nie ma znaczenia, w jaki sposób. Na przykład, aby przetrwać, organizm ludzki, jak każdy organizm zwierzęcy, musi się odżywiać. Jak długo jednak zapewnione zostaje minimum kalorii i substancji budulcowych, organizmowi „jest obojętne”, jak się go odżywia. Z tego punktu widzenia różnica między kuchnią francuską a kuchnią chińską, a nawet między kawiorem a kroplówką nie ma znaczenia. Ramowy charakter uwarunkowań funkcjonalnych powoduje, że wyznaczają one granice tego, co możliwe, i zakres tego, co niezbędne, ale nie wyjaśniają rzeczywistego kształtu konkretnych from kulturowych, na przykład różnicy między kuchnią francuską a kuchnią chińską. Wyjaśnienia funkcjonalne zatem nie mogą teorii kultury wystarczyć, podobnie jak i sama teza materializmu kulturowego. Problem ten napotkał z całą mocą Fernand Braudel, pisząc „Struktury codzienności” ${ }^{23}$, będące w dużym stopniu historią sposobów realizacji podstawowych potrzeb funkcjonalnych. Rozwiązanie, jakie przyjął, ujawnia się w odniesieniu do tzw. roślin cywilizacyjnych, a więc fundamentalnych upraw powiązanych z całokształtem historycznych cywilizacji: ryżu, pszenicy i kukurydzy. Otóż pierwotny, ginący w mrokach neolitu, wybór podstawowej rośliny, wybór „chleba powszedniego”, który wcale nie musi być chlebem, dokonuje się bez wątpienia w polu możliwości - raz jeszcze ramowo określonym - jakie tworzą geograficzne, a zwłaszcza klimatyczne i biologiczne warunki bytowania. Raz jednak dokonany, wybór ten sam staje się ogranicznikiem i ramową determinantą innych zjawisk, sam określa nowe pole możliwości. Najpierw więc człowiek musi jeść i przyroda określa, co w danym miejscu i czasie jeść może. Potem jednak, gdy człowiek wybierze np. ryż, zmienia się szczegółowy charakter ramowej determinanty: jeśli człowiek ma jeść, to musi uprawiać ryż, bez względu na to, co innego może mu przyjść do głowy. Ryż staje się „zbawcą” i „tyranem” cywilizacji i tylko jeśli będzie dość ryżu, to niektórzy będą mogli zająć się ikebaną, budo, ceremonią herbacianą, elektroniką i produkcją gier online. Jest to determinizm dziejów. Przy tym ryż nie tłumaczy oczywiście, dlaczego japoński drzeworyt różni się stylistycznie od niemieckiego, tłumaczy jedynie, dlaczego niektórzy Japończycy mogli przestać uprawiać ryż i zająć się grafiką. Tutaj materializm kulturowy napotyka swoją granicę. W każdym razie nietrudno zrozumieć, dlaczego

\footnotetext{
${ }^{22}$ Kmita 1985.

${ }^{23}$ Braudel 1992.
} 
Kmita zostawia „czyste” wyjaśnienia funkcjonalne naukom biologicznym, a naukom o kulturze przypisuje bardziej złożoną procedurę wyjaśniania funkcjonalno-genetycznego, która ujmuje także dziejowy wymiar wszelkiego ludzkiego zjawiska.

Jeśli zatem pierwszą fundamentalną wadą stanowiska Marvina Harrisa jest brak rozpoznania ramowego charakteru uwarunkowań materialnych, to drugą wadę stanowi zbagatelizowanie przez tego autora wszelkich czynników świadomościowych czy przekonaniowych. Tak na przykład obowiązujący wśród niektórych społeczności zakaz spożywania mięsa świń można zdaniem Harrisa tłumaczyć żelaznymi zasadami rachunku kalorycznego. Takie wyjaśnienie zawiera równania, a więc wygląda naprawdę „naukowo”. Nie jest też zwykłym nieporozumieniem, gdyż ukazuje coś istotnego, a mianowicie podstawy możliwości zakazu spożywania świńskiego mięsa. Otóż z przedstawionej przez Harrisa argumentacji wynika, że zakaz taki w warunkach bliskowschodnich nie pociągał za sobą istotnego obniżenia jakości wyżywienia populacji, a nawet sprzyjał korzystniejszej relacji między energią wydatkowaną na zdobycie pożywienia a energią $z$ tego pożywienia uzyskiwaną. Możemy założyć, że w sytuacji, gdyby zakaz spożywania wieprzowiny zagrażał wyżywieniu populacji, zostałby odrzucony, tak jak w warunkach ekstremalnych standardowo ulega odrzuceniu tabu kanibalizmu, i to wśród grup ludzkich należących do społeczeństw, gdzie tabu to jest bardzo silne. Wiemy więc dzięki Harrisowi, dlaczego zakaz spożywania mięsa świń mógł się utrzymać, ale - wbrew przekonaniu samego Harrisa - nie dowiadujemy się nic na temat tego, dlaczego taki zakaz w ogóle się pojawił. Rachunek kaloryczny nie wnosi do tego problemu nic, gdyż starożytni nie mogli się nim kierować, nie znając go. Sprawa dość oczywista. Sytuacja jest tutaj dość podobna, jak w przypadku tłumaczenia zakazu kazirodztwa dążeniem do zapobieżenia zwiększonej częstotliwości chorób genetycznych i utrzymania możliwie najszerszej puli genów, tak jakby tysiące lat temu ludzie posiadali pojęcie genotypu, fenotypu, puli genów i mogli rozumować w tego rodzaju kategoriach. Wątpliwe jest nawet domniemanie, że nie posiadając tych pojęć, ludzie dostrzegali negatywne skutki kazirodztwa, skoro prawo do przekroczenia tego zakazu przysługiwało jedynie najbardziej uprzywilejowanym. Możemy bezpiecznie założyć, że gdyby królowie starożytnego Egiptu albo Habsburgowie byli rzeczywiście świadomi skutków płodzenia potomstwa przez ludzi blisko spokrewnionych, to mieli wszelkie warunki po temu, by z tych niekorzystnych praktyk zrezygnować. Za każdym razem zatem otrzymujemy prawidłowe i cenne rozpoznanie skutków pewnego zakazu kulturowego - korzystniejszy bilans energetyczny, 
ograniczenie ekspresji alleli chorobowych i utrzymanie możliwie szerokiej puli genów - tłumaczące możliwość utrzymywania się tych zakazów poprzez ich efekty funkcjonalne, za każdym razem jednak ów opis zostaje błędnie przedstawiony jako wyjaśnienie genezy tych zakazów. Pomylono funkcję, genezę i sens, bowiem poznajemy funkcję, ale musimy dopiero zapytać o sens tych zakazów. Sens ów możemy poznać dopiero, badając czynniki świadomościowe: mity, przekonania moralne itp. Badając je, dowiadujemy się np., że w kręgu judeo-islamskim nie jada się wieprzowiny nie ze względu na rachunek kaloryczny, ale z uwagi na nieczysty charakter świń. Pochodzenie tego zakazu stawia więc innego rodzaju pytania niż te, do których prowadzi materialno-kulturowy punkt widzenia. Należy teraz zrozumieć kategorię nieczystości rytualnej w odróżnieniu od innych klasyfikacji aksjologicznych, opartych na przykład na kategoriach grzechu lub winy (co swoją drogą starał się uczynić Paul Ricouer w „Symbolice zła”24) oraz poszukiwać reguł klasyfikacji, które zaowocowały takim a nie innym zaklasyfikowaniem świńskiego mięsa ${ }^{25}$. Niestety, nie zawsze posiadamy wystarczające źródła, aby dokonać pełnego, genetycznego opisu tych procesów.

Nie chodzi mi więc w żadnym razie o podważenie stanowiska materializmu kulturowego, lecz o uniknięcie uproszczeń, których ofiarą padł, jak sądzę, Marvin Harris. Teza materializmu kulturowego wyznacza conditio sine qua non każdego ludzkiego społeczeństwa, wyznacza pole tego, co dla danego społeczeństwa możliwe, pozwala określić granice akceptowalności rozmaitych rozstrzygnięć kulturowych, ale nie tłumaczy w sposób wystarczający kształtu samych tych rozstrzygnięć, które niemal zawsze mogłyby być inne: czyż Chińczycy nie mogliby opanować i zagospodarować swoich gór i przez to nadać marginalnej dla nich hodowli znaczenia nie mniejszego niż zrobili to dzisiejsi Amerykanie i przez to radykalnie ograniczyć "tyranię" ryżu, a w konsekwencji wytworzyć inny typ społeczeństwa? Teza materializmu kulturowego nie tłumaczy, dlaczego tego nie uczynili, i nie może tłumaczyć tak długo, jak długo nie uwzględni, że ludzie nie działają na podstawie domniemanego rzeczywistego kształtu świata (utożsamionego zwykle z tym jego obrazem, który oferuje zachodnie przyrodoznawstwo), lecz na podstawie społecznie podzielanego i podlegającego wariacjom indywidualnym obrazu świata w rozumieniu Arona Guriewicza ${ }^{26}$. Wyrażając to inaczej: ludzkie działania, także te, które dążą do zapewnienia realizacji podstawowych potrzeb

\footnotetext{
${ }^{24}$ Ricoeur 2002.

${ }^{25}$ Douglas 1972.

${ }^{26}$ Gurevich 1992.
} 
materialnych, są dokonywane na podstawie aktualnej dla danego społeczeństwa wiedzy o rzeczywistości, a nie dzisiejszej naukowej wiedzy o niej (nawet uczeni nie działają w całości w oparciu o naukowy obraz świata, by przypomnieć sławną podkowę przybitą nad drzwiami do domu Wernera Heisenberga czy religijnie motywowane odrzucenie mechaniki kwantowej przez Alberta Einsteina). W działaniu rzeczywistość jest „wzięta ze współczynnikiem humanistycznym”, powiedziałby Florian Znaniecki, choćby treścią owego współczynnika była teoria naukowa ${ }^{27}$. Czynników świadomościowych nie da się więc pominąć bez ryzyka przekształcenia materializmu kulturowego w niemożliwą do obrony symplifikację.

\section{OGRANICZENIA RACJONALISTYCZNEJ KONCEPCJI DZIAŁANIA}

Można sobie teraz pozwolić na zebranie dotychczasowych wątków, starając się zarazem wydobyć te wnioski, które mają znaczenie dla statusu racjonalistycznego rozumienia ludzkich działań. Nie ulega zatem wątpliwości, że koncepcja racjonalistyczna wymaga dwustronnego ograniczenia:

(1) Nie wszystkie ludzkie zachowania stanowią działania racjonalne. Przyjmujemy przy tym przez cały czas wyłącznie teoriodecyzyjne rozumienie racjonalności, tzn. w szczególności nie zakładamy, że działanie racjonalne realizuje jakąś substancjalnie pojętą racjonalność, pozostaje realizacją treści Rozumu itp., ani też nie zakładamy, że działanie takie jawi się jako racjonalne pewnemu zewnętrznemu punktowi widzenia, reprezentującemu jakąkolwiek miarę domniemanej racjonalności, np. współczesną wiedzę naukową. Zakładamy jedynie, że działający podmiot jest konsekwentny względem własnego systemu przekonań (porządku preferencyjnego w rozumieniu teorii decyzji) oraz własnej wiedzy o świecie, w tym o prawdopodobieństwie realizacji celów. Podkreślmy: wiedzy własnej podmiotu, a nie zewnętrznej wiedzy obserwatora. Jest rzeczą oczywistą, że np. neurofizjologicznie warunkowane czynności odruchowe nie należą do działań racjonalnych w tym rozumieniu. Nie należałyby do nich także domniemane czynności determinowane automatyzmem nieświadomości. Nie ma potrzeby próbować teraz - co jest gigantycznym zadaniem - dokonać dyskusji możliwych klasyfikacji ludzkich zachowań. Wystarczy świadomość fundamentalnego ograniczenia: nie każda

\footnotetext{
${ }^{27}$ Znaniecki 1971
} 
ludzka czynność jest działaniem racjonalnym. Istnieją jednak takie działania, które są powiązane z systemem wartości i wiedzą o świecie działającej/działającego, i to te działania, jako powiązane z rzeczywistością myślową, jaką jest kultura, stanowią przedmiot zainteresowania teorii kultury. Leszek Nowak w tekście „O granicach paradygmatu racjonalistycznego" ${ }^{28}$ wskazywał jednak na tego rodzaju sytuacje społeczne, w których działania pozornie racjonalne mogą znaleźć się $\mathrm{w}$ sprzeczności $\mathrm{z}$ domniemaną hierarchią aksjologiczną działającego podmiotu. Rozważania Nowaka prowadzą mnie jednak nie tyle w stronę uznania proponowanych przez poznańskiego filozofa ograniczeń, związanych głównie $\mathrm{z}$ działaniem $\mathrm{w}$ warunkach totalitarnego przymusu, co raczej do sformułowania następujących zastrzeżeń: (a) inaczej niż w idealizującym, matematycznym modelu, przyjmowanym w teorii gier, porządek preferencyjny realnie działającej jednostki może być rozmyty - co może prowadzić do podejmowania odmiennych działań w podobnych lub tych samych okolicznościach - a wiedza o świecie niepewna, co owocuje zmiennością ocen podobnych okoliczności; nie ma też powodu, by porządek aksjologiczny jednostki nie zawierał biograficznie umotywowanych sprzeczności, np. o charakterze tzw. dysonansu poznawczego; (b) ludzka jednostka ma charakter dziejowy, co zewnętrznie wyraża się w posiadaniu biografii - dziejowość podmiotu powoduje diachroniczny, a więc zmienny charakter treści jej świadomości, stanowiącej przedmiot nieustannej przebudowy, prowokującej dalsze niejasności i sprzeczności; waga tego zastrzeżenia jest zmienna w zależności zarówno od uwarunkowań indywidualnych i modelu społeczeństwa, do którego przynależy dana jednostka (można bez ryzyka założyć, że dla ludzi przeszłości, umierających w świecie nie różniącym się od tego, w którym się narodzili - według określenia Gérarda Vincenta ${ }^{29}$ - czynnik ten był znacznie mniej istotny niż dla ludzi muszących adaptować się do nieustannych przemian społecznej współczesności); (c) dokładniejsza analiza działań pozornie sprzecznych z systemem wartości podmiotu ukazuje zwykle niedostateczne rozpoznanie przez obserwatora owego systemu wartości, nie zaś „nieracjonalność działań”; jeżeli ktoś np. w opisywanej przez Nowaka sytuacji „zbieszenia” podejmuje działania sprzeczne $\mathrm{z}$ wyznawaną przez siebie aksjologią, to przecież osiąga - albo tylko usiłuje osiągnąć - realizację wartości wyższej, jaką jest fizyczne przetrwanie (jeśli ktoś, zanim został poddany brutalnemu naciskowi władzy, sądził, że ceni sobie przetrwanie niżej niż np.

\footnotetext{
${ }^{28}$ Nowak 1993.

${ }^{29}$ Vincent 2000.
} 
bezwzględną uczciwość, wyrażającą się w odmowie donosicielstwa, to nowa sytuacja obnaża uprzedni stan „iluzji aksjologicznej” - nie zajmę się tutaj dalej tym zagadnieniem, gdyż wymagałoby ono obszernego wejścia w problematykę tzw. świadomości fałszywej); podobnie ktoś, kto rezygnuje z realizacji własnych wartości w imię społecznego konformizmu, ceni sobie w sposób widoczny akceptację społeczną wyżej niż owe wartości - dla rozwikływania tego rodzaju sytuacji niezbędne jest, ale też i wystarcza, odróżnienie między wartościami deklarowanymi a wartościami respektowanymi w działaniu.

(2) Drugie fundamentalne ograniczenie zasady racjonalności działań kulturowych, wskazywane przez opcje antyindywidualistyczne, zwłaszcza materializm kulturowy, ma odmienny charakter. Można pominąć strukturalistyczną tezę o sterowaniu działaniem ludzkim przez zewnętrzne względem niego społeczno-kulturowe "gramatyki”. „Gramatyki” te, niewątpliwie realne, określają przede wszystkim treści świadomości (przekonania aksjologiczne i poznawcze), a więc osiągają efekt poprzez kształtowanie subiektywno-racjonalnej determinanty działania. Choć to zaskakujące, opcje strukturalistyczne, tak gwałtownie atakujące podmiotowy humanizm („śmierć człowieka”), można łatwo pogodzić z koncepcją działania racjonalnego, gdyż ta nie wypowiada się na temat pochodzenia treści świadomości i nie potrzebuje tradycyjnego humanizmu. Więcej nawet, w wersji Jerzego Kmity wprost przyjmuje się społeczną czy też „systemową” genezę tych treści. Ograniczenie natomiast wynikające $\mathrm{z}$ tezy materializmu kulturowego (w moim przekonaniu niemożliwej do odrzucenia) można wyrazić następująco: bez względu na jakiekolwiek czynniki świadomościowe efekty czynności racjonalnych muszą zapewnić reprodukcję materialną i symboliczną. Wymóg ten działa jako reguła selekcji zachowań i treści świadomości. Jeśli zachowania i przekonania dysfunkcyjne przekraczają próg zapewnienia tego rodzaju reprodukcji (każdy system ma pewien margines tolerancji dla „usterek”), zostaną one wyeliminowane na jeden $\mathrm{z}$ trzech sposobów: (a) jednostki zastąpią zachowania dysfunkcyjne zachowaniami funkcjonalnymi; (b) jednostki pozostaną przy zachowaniach dysfunkcyjnych, co doprowadzi do usunięcia tych jednostek (autodestrukcja); (c) dominująca część społeczeństwa usunie przemocą dysfunkcyjne zachowania lub podejmujące je jednostki (od leczenia i domu poprawczego po karę śmierci). Materializm kulturowy rozpoznaje zatem niezbędną ramę dla możliwych działań i tworzonych przez nie praktyk. 


\section{WNIOSKI}

Jak zatem usytuować względem siebie racjonalne działanie i ograniczającą je funkcjonalną ramę? Kmita proponował ich hierarchizację, przyznając prymat uwarunkowaniom funkcjonalnym, wbrew humanistycznej koncepcji działającego podmiotu. Taka decyzja autora „Kultury i poznania” po pierwsze porządkuje logicznie system eksplanacji stosowany w teorii kultury, a po wtóre pozostaje $\mathrm{w}$ zgodzie $\mathrm{z}$ faktem, że zasadnicze wymogi funkcjonalne muszą być spełnione bezwyjątkowo. Niełatwo więc z decyzją tą dyskutować. Pozwolę sobie jednak skomplikować sytuację, podkreślając trzy czynniki. Po pierwsze, relacja między potrzebą systemową (funkcją) a realizowaną w działaniu wartością (sensem) jest wyjątkowo złożona. Działanie może być skupione na sensie, ale mimowolnie realizować funkcję (ktoś chodzi do kościoła, by uniknąć wiecznego potępienia - sens - a realizuje zasadę integracji społecznej - funkcja). Można sobie uświadomić funkcje działań i uczynić je ich sensem, utożsamić funkcję i sens (nie wierzę w Boga, ale chrzczę dzieci, by nie stawiać ich w sytuacji wykluczenia społecznego). Uświadomienie takie może być czasem osiągnięciem jedynie dominującej części społeczeństwa, która potrafi manipulować inną jego częścią (nie wierzę w Boga, ale podejmuję działania, by inni wierzyli, gdyż gwarantuje mi to sprawne funkcjonowanie podporządkowanych warstw społecznych - na tym polega jedna z form tzw. zarządzania). Można sobie wyobrazić dalsze scenariusze. Po drugie, podkreślmy raz jeszcze, ludzie nie działają na podstawie tego, jaki świat „obiektywnie jest”, lecz na podstawie tego, co o nim wiedzą. Mogą „źle” rozpoznawać efekty swych działań, podejmować błędne korekty, nieudane eksperymenty itd., mogą nawet $\mathrm{z}$ całym ryzykiem autodestrukcji kontestować porządek funkcjonalny, a wreszcie $\mathrm{w}$ działaniach skutecznych mogą być, i wielokrotnie są, wynalazczy. Po trzecie i najważniejsze, ludzkie działania nieustannie zmieniają materialne warunki społecznej praktyki, a więc człowiek niejako „produkuje” warunki własnego działania. Jest to jeden $\mathrm{z}$ ważniejszych wymiarów geologicznej koncepcji „antropocenu” czy humanistycznej koncepcji „kapitałocenu”. Te trzy powody skłaniają mnie, aby - mimo wszelkich prowokowanych przez to kłopotów logicznych - zrezygnować z hierarchicznego podporządkowania czynników świadomościowych czynnikom funkcjonalnym i bronić ich ujęcia interakcyjnego lub, jeśli ktoś woli, dialektycznego. Wzorem jest tutaj dla mnie sposób myślenia przyjmowany przez Fernanda Braudela w jego analizach zależności życia społecznego i warunków geogra- 
ficznych oraz typ interakcji opisywany przez Arnolda J. Toynbee'ego ${ }^{30} \mathrm{w}$ modelu „dialektyki wyzwania i odpowiedzi”. Po jednostronnej koncentracji na świecie wiedzy (teorie dyskursu po Michelu Foucaulcie, choć w niewielkim stopniu sam Foucault) oraz po jednostronnym, choć zrozumiałym podkreśleniu czynników materialnych kosztem świadomościowych (tzw. nowy materializm Brunona Latoura), nowsze ujęcia teoretyczne wydają mi się zmierzać właśnie w stronę ujęć interaktywnych, ku pewnej koncepcji feedback. Świadczy o tym kształt współczesnych teorii praktyk (społecznych?, kulturowych?), na przykład w wersji proponowanej ostatnio przez Agatę Skórzyńską ${ }^{31}$.

$\mathrm{Na}$ koniec jedno nieobowiązkowe i nienaukowe zastrzeżenie o dużej dla mnie wadze. Jawiący się tutaj obraz rzeczywistości społecznej trudno uznać za sympatyczny lub pocieszający. Oto ostatecznie coś sprzyja lub nie sprzyja społecznej i symbolicznej reprodukcji i w drugim wypadku ulega eliminacji. Taki wydaje mi się niestety stan rzeczy. Jednostkowa swoboda i dobrobyt dzisiejszych Europejczyków nie wydaje mi się na przykład zasługą demokracji, wolności czy społecznej solidarności, ale efektem odkrycia, że system bogatych i samozadowolonych konsumentów lepiej reprodukuje stosunki władzy i lepiej pomnaża kapitał niż system nędzarzy na granicy rewolucji. Spokojnie zatem, o ile nie będzie jakiejś katastrofy, nędza do Europy nie wróci, gdyż jest niefunkcjonalna. Dzisiejsze społeczeństwo afirmuje systemowy konformizm w sposób skrajny i dobrze mu to służy. Źle to służy zadłużonym Brazylijczykom i przymusowym robotnikom z zachodnich Chin, ale dysfunkcyjne kwestionowanie skutecznego systemu jest równie skutecznie eliminowane. Jedna tylko uwaga: rozpoznanie sytuacji nie oznacza jej afirmacji. To są dwa różne porządki. Gorzej jest rozpoznać błędnie i wziąć za dobrą monetę funkcjonalnie potrzebne ideologie.

\section{RATIONALITY OF ACTION AND ITS LIMITATIONS}

\section{Summary}

The essential aim of the paper is to examine the boundaries of applicability of the assumption presupposing rationality of human action or the so-called "rationalistic paradigm" in humanities and social sciences. "Rational action" itself is construed here along the lines of decision theory, i.e. as an action compliant with the axiological

\footnotetext{
${ }^{30}$ Toynbee 2000.

${ }^{31}$ Skórzyńska 2017.
} 
hierarchy adopted by the acting subject and their knowledge of the circumstances of action. Given that the rationality premise is essentially a methodological assumption - which in the explanatory structure correlates the action of the subject with their convictions - rather than an empirical psychological proposition, questions about the nature of human action are not asked here. The author is concerned with the efficacy of explanations based on such an assumption and the confines of its applicability. Two fundamental limitations of the rationalistic paradigm are therefore examined: (1) the possibility or necessity of adopting non-rationalistic theoretical models of human action in elucidation, and (2) the structures of accounting for social phenomena which assume various forms of methodological anti-individualism. Although the author recognizes the necessity to use other models alongside the rational one, given that certain types of human action cannot be accounted for with rational explanation, anti-individualistic options are the primary object of attention. Examination of the latter yields the conclusion that at least those anti-individualistic explanations which take the form of the most broadly construed cultural materialism cannot be dismissed without a considerable detriment to the explanatory potency of social sciences. Thus the need to sustain the rationality premise in explaining individual actions and fundamental assumptions of cultural materialism when trying to account for collective phenomena leads to a classic methodological and theoretical quandary relating to the reciprocal relations of both explanatory modes, or the relation between the sense and function of action. The author thus discusses two models of the relationship: the hierarchical one, adopted by Jerzy Kmita, and the interactional one, characteristic of the French school of sociological-historical inquiry.

\section{Bibliografia}

Ajdukiewicz K. 2006, O stosowalności czystej logiki do zagadnień filozoficznych, [w:] Język i poznanie, Warszawa, s. 211-214.

Alexander J.C. 1978, Formal and Substantive Voluntarism in the Work of Talcott Parsons: A Theoretical and Ideological Reinterpretation, American Sociological Review, 43, s. 177-198. Braudel F. 1992, Kultura materialna, gospodarka i kapitalizm. VI-XVIII wiek, Warszawa.

Davidson D. 1991, Zdarzenia mentalne, [w:] B. Stanosz (red.), Empiryzm współczesny, Warszawa, s. 258-279.

Derrida J. 1986, Struktura, znak i gra w dyskursie nauk humanistycznych, Pamiętnik Literacki, 2.

Douglas M.1972, Deciphering a Meal, Daedalus, 101, 1, s. 61-81.

Freud S. 2013, Kultura jako źródło cierpień, Warszawa.

Gurevich A. 1992, Historical Anthropology of Middle Ages, Chicago.

Jung C.G. 1976, Archetypy i symbole. Pisma wybrane, Warszawa.

Harris M. 2001, Cultural Materialism: The Struggle for a Science of Culture, Walnut Creek.

Harris M. 2001a, The Rise of Anthropological Theory: A History of Theories of Culture, Walnut Creek.

Kmita J. 1985, Kultura i poznanie, Warszawa.

Lacan J. 1995, Funkcja i pole mówienia i mowy w psychoanalizie, Wrocław. 
Lakoff G. i Johnson M. 1988, Metafory w naszym życiu, Warszawa.

Lévi-Strauss C. 1969, Myśl nieoswojona, Warszawa.

Lévi-Strauss C. 1992, Smutek tropików, Łódź.

Lévi-Strauss C. 2001, Wprowadzenie do myśli Marcela Maussa, [w:] M. Mauss, Socjologia i antropologia, Warszawa, s. 7-39.

Lomax A. 1968, Folk Song Style and Culture, New Brunswick.

Malinowski B. 2000, Kultura i jej przemiany, Warszawa.

Mauss M. 2001, Socjologia i antropologia, Warszawa.

Nowak L. 1993, O granicach paradygmatu racjonalistycznego, [w:] K. Zamiara (red.), Humanistyka jako autorefleksja kultury, Poznań, s. 207-219.

Ricoeur P. 2002, Symbolika zła, Warszawa.

Skórzyńska A. 2017, Praxis i miasto, Warszawa.

Steward J.H. 1972, Theory of Culture Change: The Methodology of Multilinear Evolution, Champaign.

Toynbee A.J. 2000, Studium historii. Skrót dokonany przez D. C. Somervella, Warszawa.

Vincent G. 2000, Historia sekretu, [w:] A. Prost i G. Vincent (red.), Historia życia prywatnego, 5, Od I wojny światowej do naszych czasów, Wrocław, s. 163-410.

Znaniecki F. 1971, Nauki o kulturze, Warszawa.

Žižek S. 2001, Przekleństwo fantazji, Wrocław. 